\title{
EFFECT OF Faba bean VARIETIES AND PHOSPHORUS FERTILIZATION ON THE POPULATION DENSITY APHIDS AND THRIPS IN QALUBIA GOVERNORATE.
}

\author{
El-Khayat, E. F. ${ }^{1}$; M. F. A. H. Hegab $^{2}$; I. A. Gaaboub ${ }^{1}$; \\ Rasha A. El-Hosary ${ }^{1}$ and Aml E. Gouda ${ }^{2}$
}

- Department of Plant Protection Fac. of Agric. ,Benha Uvi. ,Egypt

- Plant Protection Research Institute, A.R.C .,Dokki. ,Eygpt

\begin{abstract}
Experiments were conducted during the three seasons of 2010/11and2011/12 and2012/13 at the Experimental Research Station in Moshtohor, Faculty of Agric ,Benha Unv. ,Qalubia Governorate, Egypt. Three phosphorus fertilization levels (0, 100 , and $200 \mathrm{~kg} / \mathrm{fed}$ ) were applied to clarify their effects on the population density of aphid spp and thrips (Thrips tabaci). in Faba bean fields, its relationship with chemical components on leave sand susceptibility of the two varieties (Giza843 and sakha2). The obtained results showed that the highest population densities of these pests occurred at no phosphorus fertilization(control) followed by $100 \mathrm{~kg} / \mathrm{fed}$, . The lowest population densities were recorded for the treatment at $200 \mathrm{~kg} / \mathrm{fed}$. On the other hand, sakha2 var .received the lowest infestation. Significant differences between the means of chemical components in leaves of Faba bean plants were obtained.
\end{abstract}

\section{INTRODUCTION}

Faba bean (Vicia faba $L$ ) is one of the most important economic crops grown in Egypt. Seeds of broad bean has highly protein content, are used either as fresh green vegetable or dried for human and animal feeding Duke(1981).Faba bean plants is liable to attack by several insect pests, from the early stage of growth through the late development to the post harvest stage. The most important insect pests in the field are aphid species, thrips and leaf miners.Certain aphid species are common as major pests of economic plants. For instance, the cowpea aphid, Aphis craccivora, (Homoptera :Aphidiade) is a polyphagus pest species of field crops especially leguminosae.It damages the plants by sucking the sap. It also considered a vector of about 30 plants virus daises. (Blackman and Eastop 1984: Saenz et.al 2001: Tawfeek, 2004, El Hawary and Abd El- Salam 2005).Legumes are inhabited by a number of pests, including thrips (Thysanoptera).Thrips damage crops by feeding directly on leaves, flowers and/or fruits (Lewis 1975, 1997). They are difficult to control because of their small size, high reproduction rates and rapid development of resistance to many insecticides(Shelton et al. 2003).

Phosphorus is very important nutrient for crop growth and high yield with good quality .It plays a key role in metabolic process such as the conversion of sugar into starch and cellulose. As a result, phosphorus deficiency causes stunting, delayed maturity and shriveled seeds (Soheir Mokhtar 2001 and Abdalla (2002):El Douby et al .(2002). 
The objective of this study was evaluating the effect of Vicia faba varieties and phosphorus fertilization on the infestation with aphids and thrips and their effects on the resultant yield.

\section{Field study:}

\section{MATERIALS AND METHODS}

Field experiment were carried out in the Experimental Research Station at Moshtohor, Faculty of Agric ,Benha Unv ,Qalubia Governorate during three successive agriculture seasons 2010/11,2011/12,2012/13 were seeded on November $17^{\text {rd }}$. Using the varieties Giza843 and Sakha2 of broad bean ,Vicia faba L,.fam ,Leguminosae. Every tested variety was replicated three times ( 3 lines for each replicate of $3 \mathrm{M}$ length ) .

1- Effect of phosphorus fertilizer on the population density aphid and thrips.

This experiment was conducted to determine the effect of three levels of phosphorus fertilizer $\left(0.01 \cdots\right.$, and $200 \mathrm{~kg} /$ fed of $\mathrm{P}_{\mathrm{r}} \mathrm{O}$ 。on the population aphid and thrips infestation. Seeds of two varieties were sown in 17 November .at the three investigated seasons. An area of about $190 \mathrm{~m}^{2}$ was divided into $1 \wedge$ plots (three replicates for each treatment, (all plots were arranged in a complete randomized block design.

Thirty leaves randomly were sampled from each treatment, weekly. Every sample was put in a paper bag, labeled, tied and transferred to the laboratory for examining and counting aphids and thrips, using the aid of a stereomicroscope.

\section{2-laboratory studies:}

Analysis of photochemical components of leaves of the tested Faba bean varieties.

leaf samples were collected during the fruiting stage, leaves of each sample were cleaned and washed with distilled water ,then quickly dried by placing gently between filter papers to remove the excess of water, leaves were placed in a drying oven at $60 c^{\circ}$ for only one day. The dried leaves were crashed to fine powder and stored in glass bottles to determine carbohydrates and total protein contents according to the methods of Pregl(1945) and Michel et al. (1956). The percentages of reduced, nonreduced and total sugars were also estimated in the dry powder using the method of Forses(1938).Also the phosphorous and potassium content were determined according to method of Troug and Meyer (1939. The conventional cultural practices were applied and no chemical pesticides used during the present study.

\section{3-Statistical analysis} Portable.

Statistical analysis for ANOVA was carried out by using SAS 9.3.1

Whereas the means were compared through LSD tests, least significant differences at $\mathrm{P}=0.05$ level. 


\section{RESULTS AND DISCUSSION}

\section{1- Effect of phosphorus fertilizer on the population density of Faba bean plants by aphid and thrips..}

The effect of three levels of phosphorus fertilization $(0,100$ and $200 \mathrm{~kg} / \mathrm{feddan}$ ) on the population density of aphids and thrips infesting Faba bean plants were studied during the three successive seasons of 2010/11,2011/12and 2012/13.

a- Aphid (Aphis craccivora w.)

Data in Table (1) showed that there are obvious differences between the insect population in the three seasons. The plants in the first season $2010 / 2011$ harbored higher population of aphids than the two other seasons . Results also showed that the addition of phosphorus fertilizer minimize the aphid population. The level of $200 \mathrm{~kg} / \mathrm{fed}$ recorded the lowest population of aphid lasted to23.57,6.63 and 3.69 indivi /10leaves during 2010/11,2011/12 and 2012/13 Faba bean seasons, followed by the level of $100 \mathrm{~kg} / \mathrm{fed}$ recorded 28.8,8.6 and 5.2 indivi /10 leaves, respectively. The high number of aphid population recorded on the plants which don't receive any phosphorus fertilization( 35.81,13.6 and 9.18 individuals /10 leaves for the treatment of $0,0 \mathrm{~kg} / \mathrm{fed}$ of $\mathrm{P}_{2} \mathrm{O}_{5}$, respectively. This trend was found and recorded in the three season of cultivation with significant differences.

In accordance with such results ,El- Hosary(2001)mentioned that the average number of aphids in both seasons significantly decreased by increasing P-levels up to $60 \mathrm{~kg} / \mathrm{fed}$.

b- Thrips(Thrips tabaci L.):

Obtained results in tables (2)demonstrate that the lowest mean of thrips counts were recorded on Faba bean plants received 200 units of $\mathrm{p}_{2} \mathrm{O}_{5} /$ fed, lasted to $9.5,5.37$ and 3.01indivi /10 leaves, in 2010/11,2011/12 and 2012/13 Faba bean tested seasons, respectively. Followed by using 100kg/fed,12.6, 7.1 and4.7indiv /10 leaves, in 2010/11, 2011/12 and 2012/13 Faba bean seasons .respectively. While the highest population densities of thrips were $14.96,10.13$ and 6.31 indivi /10 leaves, in 2010/11,2011/12 and 2012/13 Faba bean seasons, respectively, occurred with 0.0 fertilizer (control) 2010/11,2011/12 and 2012/13Faba bean seasons ,respectively.

Similar results were obtained by ,Asiwe,J.A. N.(2009)who mentioned that damage by $A$. craccivora, $M$. sjostedti and $M$. vitrata were significantly $(P$ $<0.05$ )lower at 30 and $45 \mathrm{~kg} \mathrm{P}_{2} \mathrm{O}_{5}$ ha- 1 and consequently higher grain yields were obtained. 
Table 1 :Effect of phosphorus fertilization on the total number and mean of aphids $A$. craccivora Faba bean during three successive seasons at Qalubia Governorate .

\begin{tabular}{|c|c|c|c|c|c|c|}
\hline \multirow{3}{*}{$\begin{array}{l}\text { Levels of } \\
\mathrm{P}_{2} \mathrm{O}_{5} / \mathrm{fed}\end{array}$} & \multicolumn{6}{|c|}{ Seasons } \\
\hline & \multicolumn{2}{|c|}{$2010 / 11$} & \multicolumn{2}{|c|}{$2011 / 12$} & \multicolumn{2}{|c|}{$2012 / 13$} \\
\hline & Total & Mean & Total & Mean & Total & Mean \\
\hline 0.0 & 429.67 & $35.81 a$ & 231.167 & $13.59 a$ & 128.50 & $9.18 a$ \\
\hline 100 & 345.50 & $28.79 b b$ & 146.17 & $8.59 b$ & 73.167 & $5.23 b$ \\
\hline 200 & 282.83 & $23.57 b$ & 112.67 & $6.627 c$ & 54.67 & $3.6905 c$ \\
\hline $\begin{array}{l}\text { LSD at } \\
5 \%\end{array}$ & & 6.3873 & & 1.7769 & & 1.1961 \\
\hline
\end{tabular}

LSD=Least Significant Difference

Table 2 : Effect of phosphorus fertilization on the total number and mean of thrips (Thrips tabaci) Faba bean during three successive seasons at Qalubia Governorate.

\begin{tabular}{|l|c|c|c|c|c|c|}
\hline \multirow{2}{*}{$\begin{array}{l}\text { Levels of } \\
\mathbf{P}_{2} \mathbf{O}_{5} / \mathrm{fed}\end{array}$} & \multicolumn{2}{|c|}{$\mathbf{2 0 1 0 / 1 1}$} & \multicolumn{2}{|c|}{$\mathbf{2 0 1 1 / 1 2}$} & \multicolumn{2}{|c|}{$\mathbf{2 0 1 2 / 1 3}$} \\
\cline { 2 - 7 } & Total & Mean & Total & Mean & Total & Mean \\
\hline 0.0 & 179.49 & $14.96 \mathrm{a}$ & 172.33 & $10.14 \mathrm{a}$ & 88.33 & $6.31 \mathrm{a}$ \\
100 & 150.99 & $12.58 \mathrm{~b}$ & 120.49 & $7.09 \mathrm{~b}$ & 66.17 & $4.73 \mathrm{~b}$ \\
200 & 114 & $9.50 \mathrm{c}$ & 91.33 & $5.37 \mathrm{c}$ & 42.17 & $3.01 \mathrm{c}$ \\
\hline LSD at $5 \%$ & & 1.965 & & 1.4916 & & 0.8339 \\
\hline
\end{tabular}

2- Effect of Faba bean varieties on population density of aphids $A$. craccivora and Thrips(Thrips tabaci L.):

The obtained results indicated that there were a significant differences $(P>0.05)$ between the mean numbers of aphids among the two tested varieties .During second and third seasons 2011/12 \&2012/13 table (3), but there are insignificant differences between the two varieties in the first season 2010/2011.The highest mean number of aphids was recorded on Giza 843 var, being 31,11.4 and 6.9 indivi/10 leaves during the three successive seasons, respectively. The lowest infestation was observed on Sakha2, lasting to27.8,7.8 and 6.9indivi/10 leaves during the three tested successive seasons, respectively. 
Table 3: Effect of two varieties on the total number and mean of Faba bean during three successive seasons at Qalubia Governorate.

\begin{tabular}{|l|c|c|c|c|c|c|}
\hline \multirow{2}{*}{ Varieties } & \multicolumn{6}{|c|}{ Seasons } \\
\cline { 2 - 7 } & \multicolumn{2}{|c|}{$\mathbf{2 0 1 0 / 1 1}$} & \multicolumn{2}{c|}{$\mathbf{2 0 1 1 / 1 2}$} & \multicolumn{2}{|c|}{$\mathbf{2 0 1 2 / 1 3}$} \\
\cline { 2 - 7 } & Total & Mean & Total & Mean & Total & Mean \\
\hline Sakha2 & 403.25 & $27.76 \mathrm{a}$ & 133.12 & $7.83 \mathrm{~b}$ & 71.33 & $5.09 \mathrm{~b}$ \\
\hline Giza 843 & 360.87 & $31.019 \mathrm{a}$ & 193.55 & $11.38 \mathrm{a}$ & 97.56 & $6.97 \mathrm{a}$ \\
\hline LSD at 5\% & & 5.2152 & & 1.4509 & & .9766 \\
\hline
\end{tabular}

Table 4: Effect of two varieties of on the total number and mean of thrips (Thrips tabaci) Faba bean during three successive seasons at Qalubia Governorate

\begin{tabular}{|l|c|c|c|c|c|c|}
\hline \multirow{2}{*}{ Varieties } & \multicolumn{7}{|c|}{ Seasons } \\
\cline { 2 - 7 } & \multicolumn{2}{|c|}{$\mathbf{2 0 1 0 / 1 1}$} & \multicolumn{2}{|c|}{$\mathbf{2 0 1 1 / 1 2}$} & \multicolumn{2}{|c|}{$\mathbf{2 0 1 2 / 1 3}$} \\
\cline { 2 - 7 } & Total & Mean & Total & Mean & Total & Mean \\
\hline Sakha2 & 146.731 & $11.2870 \mathrm{~b}$ & 113.339 & $6.6667 \mathrm{~b}$ & 59.66 & $4.2619 \mathrm{~b}$ \\
\hline Giza 843 & 174.2962 & $13.4074 \mathrm{a}$ & 142.779 & $8.3987 \mathrm{a}$ & 71.448 & $5.1032 \mathrm{a}$ \\
\hline $\begin{array}{c}\text { LSD at } \\
5 \%\end{array}$ & & 1.6051 & & 1.2179 & & 0.6809 \\
\hline
\end{tabular}

\section{B-Thrips(Thrips tabaci)}

The obtained results indicated that there were significant differences $(P>0.05)$ between the mean numbers of thrips among the tested varieties, during the three successive seasons (2010/11, 2011/12 and 2012/13) table (4), then, the highest mean number of thrips infestation was recorded on Giza 843 var, being $13.4,8.4$ and 5.1 indivi/10 leaves during three successive seasons, respectively. The lowest infestation was observed on Sakha2var, being 11.29,6.67 and 4.26indiv /10 leaves e during three successive seasons, respectively.

From the previous results, it could be concluded that the two tested Faba bean varieties were variably infested with aphids, and thrips, during three successive seasons2010/11,2011/12 and 2012/13with significant differences.

Similar results were obtained by,Ebadahet al.(2006)Described the susceptibility of six Faba bean varieties (Giza 714, G716, G843, G429, G643and G461) to infestation with legume aphids, Aphis craccivora(Koch), Results show that the six tested varieties showed different susceptibility to the three insect pests.

3- Chemical analysis of Faba bean leaves induced by different levels of phosphorus fertilizers and infestation of aphid and thrips in 2011/12 season.

Data recorded in Table (5), show a significant differences between the means of chemical components in the leaves of Faba bean plants treated with different levels of phosphorus fertilizer during 2011/12 season. The 
lowest abundance of thrips and aphids occurred on leaves of Faba bean plants $\left(6.6275\right.$ and 5.3725 indivi $/ 10$ leaves, treated with $200 \mathrm{~kg} / \mathrm{fed}$ of $\mathrm{p}_{2} \mathrm{O}_{5}$ associated with higher levels of protein, (14.91 mg/gm dry weight),T. Carbohydrate $(12.94 \mathrm{mg} / \mathrm{gm}$ dry weight),Total sugars $(8.758 \mathrm{mg} / \mathrm{gm}$ dry weight),Non-reduce sugars(4.85 mg/gm dry weight), phosphor(0.75 mg/gm dry weight), and potassium( $32.44 \mathrm{mg} / \mathrm{gm}$ dry weight) respectively, in addition there no significant difference between treatments in reduce sugars Ghallabet.al(2014) indicated that the population abundance of B. tabaci, adults on bean plants during high infestation showed significantly relation with total protein and total sugar. While, negative correlation value was calculated in case of phosphorus fertilizers.

Table (5):Chemical analysis of Faba bean leaves induced by different levels of phosphorus fertilizers during 2011/12 season.

\begin{tabular}{|l|c|c|c|c|c|c|}
\hline $\begin{array}{l}\text { Level } \\
\text { of } \mathbf{p}_{\mathbf{2}} \mathbf{O}_{\mathbf{5}}\end{array}$ & $\begin{array}{c}\text { Total. } \\
\text { Carbohydrate }\end{array}$ & $\begin{array}{c}\mathbf{T} . \\
\text { sugars }\end{array}$ & $\begin{array}{c}\text { reduce } \\
\text { sugars }\end{array}$ & $\begin{array}{c}\text { Non- } \\
\text { reduce } \\
\text { Sugars }\end{array}$ & Phosphor & Potassium \\
\hline 0.0 & $12.56 \mathrm{c}$ & $8.24 \mathrm{c}$ & $3.90 \mathrm{aa}$ & $3.85 \mathrm{c}$ & $0.75 \mathrm{c}$ & $31.13 \mathrm{ab}$ \\
\hline 100 & $12.768 \mathrm{~b}$ & $8.468 \mathrm{~b}$ & $3.80 \mathrm{aa}$ & $4.51 \mathrm{~b}$ & $0.70 \mathrm{~b}$ & $28.98 \mathrm{bb}$ \\
\hline 200 & $12.94 \mathrm{a}$ & $8.758 \mathrm{a}$ & $3.88 \mathrm{aa}$ & $4.85 \mathrm{a}$ & $0.75 \mathrm{a}$ & $32.44 \mathrm{aa}$ \\
\hline L S D & 0.0968 & 0.1242 & 0.2131 & 0.3684 & 0.0265 & 2.1524 \\
\hline
\end{tabular}

4-Yield:

Effect of the treatment with phosphorus fertilizer on the field of Faba bean.

Data presented in tables (6) show that the yield of Faba bean plants treated with the different tested treatments of three levels of phosphorus fertilizer was highly significant in three season .The largest weight of dray seeds yield during 2010/11,2011/12 and 2012/13seasons recorded $1199.3,1166.7$ and $1143.3 \mathrm{~kg} / \mathrm{fed}$, respectively , while the lowest weight of dray seeds yield were $616,816.7$ and $812 \mathrm{~kg} / \mathrm{fed}$, respectively occurred with 0.0 fertilizer (control) during 2010/2011,2011/2012 and 2012/2013 Faba bean seasons ,respectively .Followed with by using $100 \mathrm{~kg} / \mathrm{fed}, 984.7,1082.7$ and 1082.7k g/ fed, in2010/11, 2011/12 and 2012/13 Faba bean seasons ,respectively.

This result agree with Getachew and Angaw (2006)who Studied the effect of phosphorus fertilizer on the yield and yield components of Faba bean. Five levels of phosphorus fertilizer were used. Results indicated a positive linear response of Faba bean seed yield to phosphorus fertilizer applications. Plant height, number of pods per plant, nodulation score and plant biomass of Faba bean were positively, agree with Hashem abadi (2013).

Effect of two Faba bean varieties on the yield.

Data recorded in Tables $(4,5 \& 6)$, show the means of Faba bean yield produced by two varieties during 2010/11,2011/12 and 2012/13 season.The highest total grain yield was obtained by Sakha2 cultivar, recorded 1124, 1115.3and1054.7kg/fed during 2010/11,2011/12 and 2012/13 Faba bean seasons, respectively .Followed by Giza843 cultivar recorded 877.3,942 
and971.7 kg/fed during 2010/11,2011/12 and 2012/13Faba bean seasons ,respectively .

Means of harvested Faba bean grain yield fedan proved that there is a significant difference between sakha2 cultivar and Giza $843(P<0.05)$, L.SD=40.28,29.9 and 29.17 through the three seasons.

Table (6) :Effect of the treatment with phosphorus fertilizer on the field of Faba bean during three seasons 2010/2011,2011/2012 and 2012/2013.

\begin{tabular}{|l|c|c|c|c|c|c|}
\hline & \multicolumn{2}{|c|}{$\mathbf{2 0 1 0 / 1 1}$ Season } & \multicolumn{2}{|c|}{$\mathbf{2 0 1 1 / 1 2}$ Season } & \multicolumn{2}{|c|}{ 2012/13 Season } \\
\hline $\begin{array}{l}\text { Level of } \\
\mathbf{p}_{\mathbf{2}} \mathbf{O}_{\mathbf{5}}\end{array}$ & Yield & $\begin{array}{c}\text { Wight of } \\
\mathbf{1 0 0} \\
\text { seeds }\end{array}$ & Yield & $\begin{array}{c}\text { Wight of } \\
\mathbf{1 0 0} \\
\text { seeds }\end{array}$ & Yield & $\begin{array}{c}\text { Wight of } \\
\mathbf{1 0 0} \\
\text { seeds }\end{array}$ \\
\hline 0.0 & 616 & 82.83 & 816.6 & 85.33 & 812 & 80.00 \\
\hline 100 & 984.7 & 86.17 & 1082.7 & 84.58 & 1082.7 & 80.00 \\
\hline 200 & 1199.3 & 86.17 & 1166.7 & 80.50 & 1143.3 & 85.00 \\
\hline L S D & 49.328 & 5.5059 & 36.662 & 5.9543 & 35.722 & 11.701 \\
\hline
\end{tabular}

Table (7) : - Effect of two Faba bean varieties on the resultant yield during three season 2010/2011,2011/2012 and 2012/2013.

\begin{tabular}{|l|c|c|c|c|c|c|}
\hline \multirow{2}{*}{ Varieties } & \multicolumn{2}{|c|}{ 2010/2011 Season } & \multicolumn{2}{|c|}{ 2011/2012 Season } & \multicolumn{2}{|c|}{ 2012/2013 Season } \\
\cline { 2 - 7 } & Yield & $\begin{array}{c}\text { Wight of } \\
\mathbf{1 0 0} \text { seeds }\end{array}$ & Yield & Yield & $\begin{array}{c}\text { Wight of } \\
\mathbf{1 0 0} \text { seeds }\end{array}$ & Yield \\
\hline Sakha2 & $1124 \mathrm{a}$ & $94.67 \mathrm{a}$ & $1153.3 \mathrm{a}$ & $1124 \mathrm{a}$ & $94.67 \mathrm{a}$ & $1153.3 \mathrm{a}$ \\
\hline Giza 843 & $877.3 \mathrm{~b}$ & $76.89 \mathrm{~b}$ & $924 \mathrm{~b}$ & $877.3 \mathrm{~b}$ & $76.89 \mathrm{~b}$ & $924 \mathrm{~b}$ \\
\hline LSD at 5\% & 40.276 & 4.4955 & 29.934 & 40.276 & 4.4955 & 29.934 \\
\hline
\end{tabular}

\section{REFERENCES}

AbdAlla, A.M., 2002. Effectof bio- and mineral phosphorus fertilizer on the growth, productivity and nutritional value of faba bean. Egypt. J. Hort.,29(2): 187-203.

Asiwe, J. A. N.2009. The impact of phosphate fertilizer as a pestmanagement tactic in four cowpea varieties. African Journal of Biotechnology Vol. 8 (24), pp. 7182-7186.

Blackman, R.L. and Eastop V.F. 1984.Aphids on the world's crops; An identification and information guide. John Wiley \& Sons, Chichester, New York Brisbane, Toronto, Singapore, 463 pp.

Duke, J.A.,1981. Hand book of legumes of world economic importance. Plenum press, New York.PP:199-265

El Douby, K.A. and G.A. Samia Mouhamed, 2002.Effect of tillage , phosphorus fertilization and weed control on Faba beanand estimation contributions of yield component statistically.Egypt. J. Agric. Res., 80(1): 253-274

El-Hawary, F. M. A. and Abd El-Salam, A. M. E. 2005.Insecticidal effects of Fenugreek oil and benzaldehyde (aromatic compounds) on cowpea aphid, Aphis craccivora Koch. J. Egypt. Ger. Soc. Zool, 46E, 1: 43 56. 
El- Hosary .A. R.2001 .Effect of some agricultureal practices on Faba beaninfestation with certain insect pests. Thesis, fac.of Agri .,Moshtohor .Benha .univ.

Forsee,W.T.1938.Determination of sugar inplant material a photo colormetric method .Inds. Eng.Chem.Ann.10 ${ }^{\text {th }}$ ed.:411-418.

Getachew Agegnehu; Angaw Tsige (2006) : The role of phosphorus fertilization on growth and yield of Faba beanon acidic Nitisol of central highland of Ethiopia.

Hashemabadi, D. 2013. Phosphorus fertilizers effect on the yield and yield components of Faba bean(Vicia faba L.). Annals of Biological Research; 2013. 4(2):181-184.

I.M.A. Ebadah, Y.A. Mahmoud and S.S. Moawad2006.Susceptibility of Some Faba beanCultivars to Field Infestation with Some Insect Pests.Research Journal of Agriculture and Biological Sciences, 2(6): 537-540

Lewis T, 1975.Thrips their biology, ecology and economicimportant. London, New York Academic Press.

Lewis T, 1997. Pest thrips in perspective. In: Lewis, T (Ed.)1997: Thrips as Crop Pests. CAB International, Cambridge.1-14.

Mona M. Ghallab1; Marguerite A. Rizk1; Wahba, B.S'. and Zaki,A.Y2 2014. Impact of different types of fertilizers to reduce the population densityof the sap sucking pests to bean plants.Egypt. Acad. J. Biolog. Sci., 7(2): $1-8$.

Michel,K.A. ;J.K.Gilles; P.A. Hamilton and F. Smith 1956 .Colorimetric method for determination of sugars and related substances .Analytical Chemistry,28(3): 302-307.

Pregl,F.1945.Quantitative organic microanalysis $4^{\text {th }}$ ed.J.andA.Chundril $4^{\text {th }}$ .London.94-101.

Sanz, N. T.; Chen, T. and Lai, P. 2001. A newly discovered mosaic disease of bush basil Ocimum basilicum in Taiwan. Plant Pathology Bulletin, 10 (4): $155--164$.

Shelton AM, Nault BA, Plate J \& Zhao JZ, 2003. Monitoring onion thrips resistance to pyrethroids in New York. Resistant Pest Management 12, 44-45.

Soheir, A. Mokhtar, 2001. Response of yield and yield components of Faba bean(Vicia faba L.) to increasing levels of nitrogen and phosphorus under two levels of plant stand density . Annals Agric. Sci. , Ain Shams Univ., Cairo, 46(1): 143-154.

Tawfeek, M.E. 2001.Studies on certain aphid species infesting some fruit trees. M. Sc.Thesis Fac. Agric. Alex. Univ.: 152 pp.

Troug ,E., and A.H., Meyer1939. Improvement in deiness colorimetric for phosphorus and arsenic .Ind.Eng.Chen.Ann.Ed., 1:136-139. 


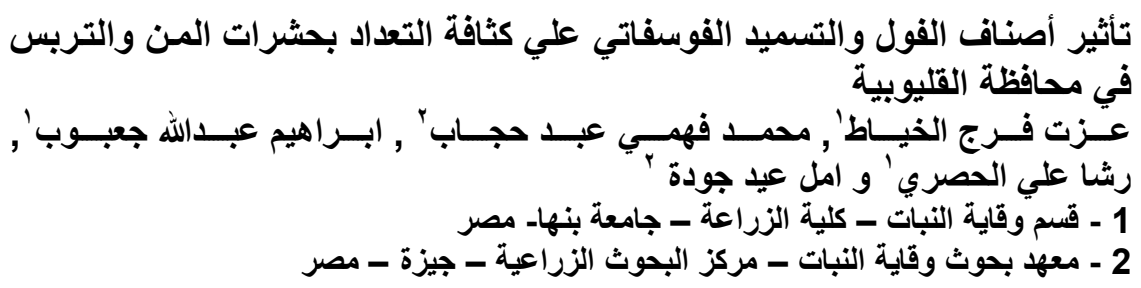

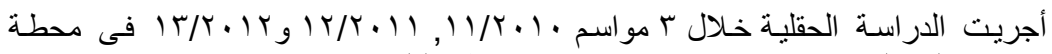

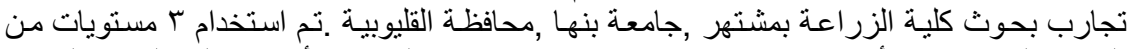



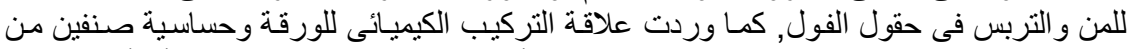

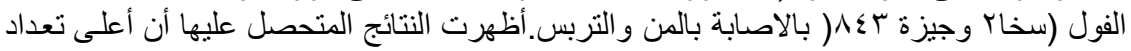

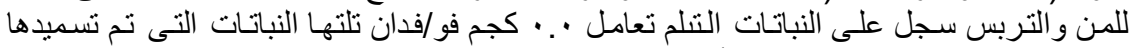

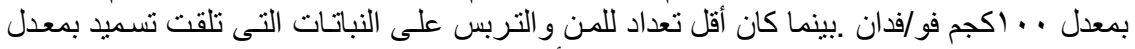

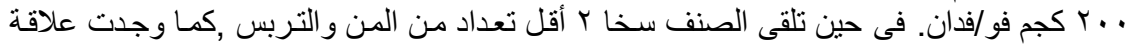

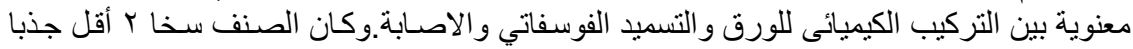

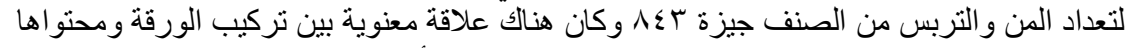

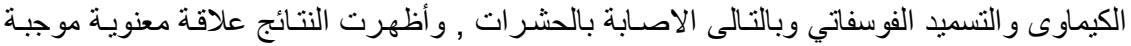

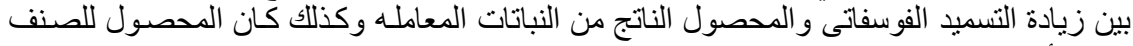

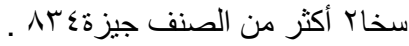

